Article

\title{
Quantitative and Qualitative Research on the Waste from the Mining of Rock Raw Materials in Lower Silesia
}

\author{
Urszula Kaźmierczak, Jan Blachowski, Justyna Górniak-Zimroz * (D) and Herbert Wirth \\ Faculty of Geoengineering, Mining and Geology, Wroclaw University of Science and Technology, \\ 50-370 Wroclaw, Poland; urszula.kazmierczak@pwr.edu.pl (U.K.); jan.blachowski@pwr.edu.pl (J.B.); \\ herbert.wirth@pwr.edu.pl (H.W.) \\ * Correspondence: justyna.gorniak-zimroz@pwr.edu.pl; Tel.: +48-71-320-6827
}

Received: 31 July 2018; Accepted: 23 August 2018; Published: 30 August 2018

\begin{abstract}
The Lower Silesia area in SW Poland is characterized by a geological structure that is conducive to mining activity. The exploitation of rock raw materials plays an important role in this sector of the economy. By the end of 2017, there were in total approximately 400 current concessions for the exploitation of rock raw materials in the analysed area (Polish Geological Institute, MIDAS database-Management and Protection System of Polish Mineral Resources). The conducted mining activity results in waste, which in the greatest amount occurs in the process of obtaining crushed road and construction aggregates, natural aggregates, carbonate raw materials for the cement and lime industry, as well as stone elements for construction and road engineering. At the end of 2016, the mining plants accumulated $26,569,600 \mathrm{Mg}$ of waste. As part of the European Regions Toward Circular Economy (CircE) project, research was conducted on the volume and composition of the mining waste of rock raw materials in the years 2010-2016 within Lower Silesia. This research used the methods of statistical, descriptive and spatial analysis to identify mining plants with the highest potential for using their wastes. In the course of this study, 6 mining plants with the highest potential of using their waste for industrial production purposes were selected. In order to objectively select these plants, the methodology of qualitative multi-criteria analysis was developed, and 7 criteria were selected for assessing the economic potential of using waste from the mining of rock raw materials. An additional result of this research is a database and graphical presentation of changes in the spatial distribution of generated waste in the Lower Silesia region in the years ranging from 2010 to 2016.
\end{abstract}

Keywords: mining waste; processing waste; rock mining; open-cast mining; multi-criteria analysis; use of waste

\section{Introduction}

According to the Polish legislation, the holder of waste is first obliged to subject such waste to a recovery process. Only if this is impossible or unjustified due to economic reasons, such waste may be subjected to disposal in the mining waste treatment facilities (MWTF). Therefore, one of the most important issues facing the mining industry is the sensible management of existing and previously unused resources of mining waste stored in MWTF. Research on the use of waste raw materials from the extraction and processing of rock raw materials is carried out in Poland and around the world [1-5]. However, the review showed that there is still a problem associated with the possibilities of using waste generated in the mining sector of rock raw materials. Therefore, the purpose of this study was to create an inventory of deposited mining and processing waste, as well as to analyse the possibilities of their management with the use of existing and/or new technologies. The research was conducted in two ways: quantitative and qualitative, which included the analysis of mining waste from the 
extraction, processing and storage of minerals from selected deposits of rock raw materials located in the Lower Silesia region (SW Poland). This research was conducted within the CircE project (European Regions Toward Circular Economy) co-financed from the European Regional Development Fund, Interreg Europe Programme. The purpose of the CircE project is to develop a regional action plan for the circular economy, along with the recommendations for regional authorities. A regional group of stakeholders from the Lower Silesia region, represented by employees of the Lower Silesia Marshal Office, indicated the need to analyse the waste management of existing and unused resources in the form of post-mining waste, deposited on the premises of active mining plants. In order to achieve this, an inventory was created containing the quantities of exploitation waste generated during the extraction and processing of rock raw materials in active mining plants in the years 2010-2016. After this, a quantitative and qualitative analysis of this waste was conducted. The conducted quantitative analysis resulted in reliable information regarding the quantity of post-mining and processing waste from selected deposits of rock raw materials located in Lower Silesia and their spatial distribution within the boundaries of administrative units (poviats). On the other hand, the qualitative analysis, which was based on the original methodology, recognized the nature and the composition of this waste, leading to the submission of a recommendation to regional authorities, companies from the studied area or companies conducting economic activity in this area, whose waste could find application for industrial production purposes over the next 3 years, due to the quantity, nature and type composition, adopting the use of technologies known around the world or new technologies.

\section{Materials and Methods}

The study focused on two aspects: (1) a quantitative-spatial and temporal analysis of the distribution of mining waste generated in rock mineral mines in the Lower Silesia region; and (2) a qualitative-analysis of the characteristics of mining waste generated in particular mine plants and an identification of rock mineral mining waste that, due to its quantity and composition, could be used for industrial production purposes with known or new technologies.

\subsection{Area and Subject of Research}

The research was carried out for the Lower Silesia region, which is located in south-western Poland (Figure 1). In geological terms, this area belongs to the most interesting regions in Poland-the Sudetes and the Fore-Sudetic Block. Almost 90\% of rock raw materials mined in Poland for the production of construction and road elements comes from the Lower Silesian deposits [6]. The number of documented deposits of rock raw materials amounted to 992 in 2017, including 553 deposits of natural aggregates, as well as 279 deposits of crushed and dimension stones [7].

It is worth noting that the Lower Silesia region is one of the most valuable areas in Poland in terms of environmental resources. This is confirmed by the fact that almost $20 \%$ of this province's area is subjected to legal protection of the environment. Hence, there are estimates that $39 \%$ of documented deposits of rock raw materials are located within environmentally valuable areas, which are often covered by one or more forms of legal protection. The system of protected areas in the region consists of: 2 national parks, 12 landscape parks, 24 protected landscape areas, 16 nature-landscape complexes, as well as many monuments and nature reserves. In addition, this system also includes Nature 2000 areas (102) constituting 14.6\% (special protection areas of birds SPA) and 17.8\% (special area of conservation SAC) of the province's area. 


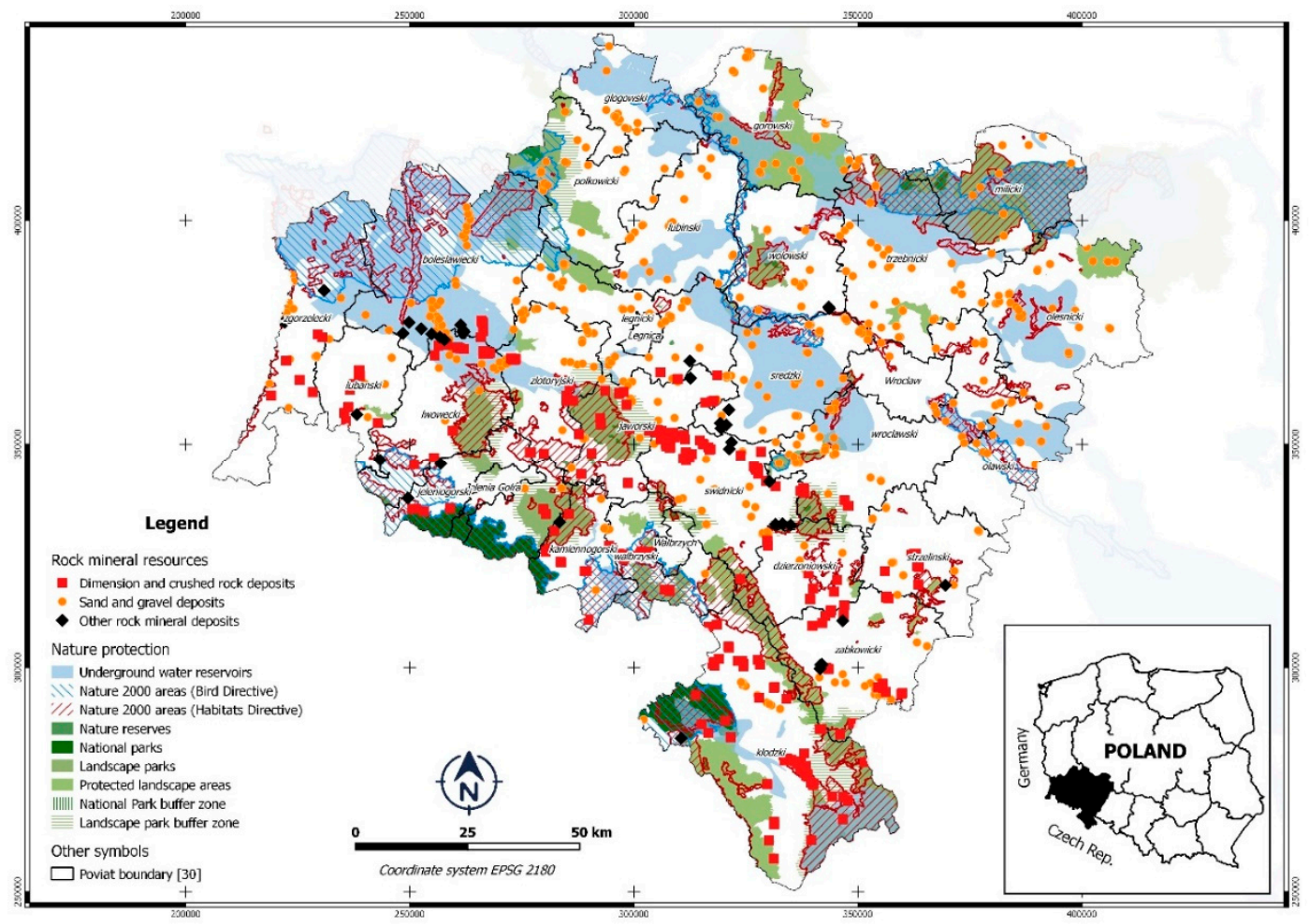

Figure 1. Location of deposits of rock raw materials against the background of protected areas and Main Underground Water Reservoirs in the Lower Silesia Province.

\subsection{Data Sources}

The sources of data concerning the inventory of deposited mining waste generated during the extraction and processing of rock raw materials consisted of information and reports obtained from institutions dealing with compilations of data regarding the types and quantities of waste, as well as methods for its management. Moreover, data regarding active mining plants operating within the studied area, as well as legally protected areas, such as Main Underground Water Reservoirs or environmentally protected areas, were also used. These thematic data were obtained from the following institutions:

- Marshal Office: compilations of data regarding the types and quantities of waste, the methods for its management, as well as installations and devices used for the recovery and neutralization of waste from the annual reports submitted by entities generating the waste (Department of Environment),

- Marshal Office: decisions approving Mining Waste Management Programs (Department of Environment),

- Marshal Office: information regarding active Mining Plants operating on the basis of mining concessions (Department of Geology),

- $\quad$ District Mining Office: information regarding active Mining Plants operating within the Lower Silesia region,

- $\quad$ Polish Geological Institute with its headquarters in Warsaw: Management and Protection System of Polish Mineral Resources MIDAS (deposits, register of mining areas, management of rock raw materials), Main Underground Water Reservoirs,

- Head Office of Geodesy and Cartography: data regarding administrative boundaries of the poviats of the Lower Silesia Region (Centre of Geodetic and Cartographic Documentation),

- $\quad$ General Directorate for Environmental Protection: areas and sites of protected environment. 


\subsection{Methodology for Quantitative Analysis}

The documentations characterizing mining waste production (spreadsheets, word files, etc.) had to be processed for a quantitative analysis. The first part consisted of a geographic information system (GIS) database development where the amount of mining waste was assigned as descriptive attributes to particular rock mineral mines in the point feature class representing their locations. The attributive database stored the amount of mining waste generated yearly between 2010 and 2016 . In addition, data was classified in terms of mining waste type (generated during the mining and during the processing of rock mineral) and in terms of the type of rock mineral: (1) dimension and crushed stones, (2) natural aggregates, (3) other rock raw minerals (e.g. clays).

In the second stage of the GIS database development for quantitative analysis, statistics were calculated for spatial reference units (administrative units) feature class (polygon). Each reference unit (at the middle-poviat-level of administration) was assigned statistical values representing the amount of waste generated each year from 2010 to 2016 based on the spatial congruence with the point feature class representing rock raw material mines. The values also included the total waste produced in this period, as well as waste generated during the mining and during the processing of the mineral. The amount of waste generated depending on the type of mineral (dimension and crushed rocks, natural aggregates, other rock raw materials) was also calculated. The GIS spatial join function in the QGIS software (Version 2.18 Las Palmas) (QGIS Development Team) was used. The database was then used to obtain graphs and diagram maps representing the spatial distribution and temporal changes of mining waste generated in rock raw material mines in Lower Silesia. The results of the quantitative analysis are presented in Section 3 of the paper.

\subsection{Methodology for Qualitative Analysis}

The qualitative analysis, being the main purpose of this study, was focused on identifying waste produced in rock raw material mines that could be considered to be used for industrial purposes and thus limit the amount of mining waste in accordance with the circular economy concept. The proposed methodology consisted of 6 main steps shown schematically in Figure 2.

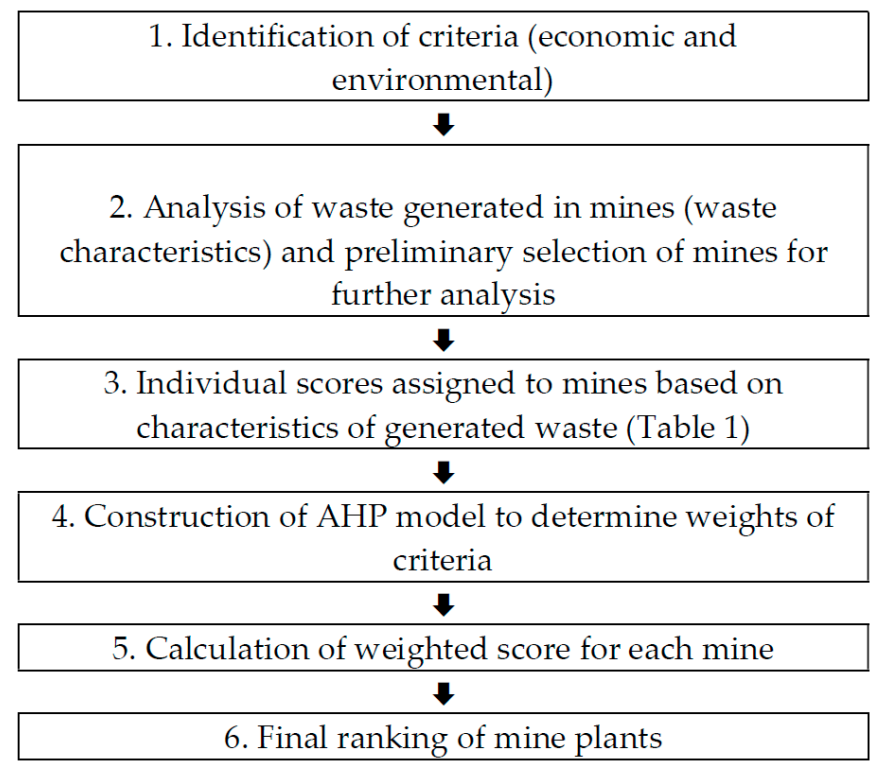

Figure 2. Scheme of methodology adopted in the study for the qualitative analysis of mining waste.

In the first step, the possible criteria determining the suitability of mining waste for industrial use were considered. Desk research of known case studies, as well as literature [8-21] in two main fields, i.e., environmental and economic factors, rendered the following criteria: (1) the type of waste 
produced (dangerous and/or inert), (2) the location of deposited waste within nature protection areas such as important underground water reservoirs, nature reserves, landscape parks, etc., (3) the raw minerals key for the national economy, (4) the amount of generated waste (above 10,000 Mg), (5) the clay minerals present in waste, (6) the sources of potassium in waste, and (7) the sources of magnesium in waste.

In the second step, waste from mineral mines was characterized and assessed in terms of the selected criteria. This reduced the number of possible candidate sites from the initial 56 rock raw mineral mines that reported waste production in the 2010-2016 period to 20 that met the above criteria.

In the next stage, each of the 20 mining sites had scores assigned in each of the 7 proposed criteria. We used a 3 point scale ( 1 to 3 ), where 1 meant the least suitable to be used for industrial purposes and 3 the most likely to be used for industrial purposes (Table 1).

Table 1. Scoring scale for each of the 7 criteria.

\begin{tabular}{ccc}
\hline $\begin{array}{c}\text { Criterion } \\
\text { (No./Name) }\end{array}$ & Description & Score \\
\hline 1. Type of waste & Dangerous & 3 \\
& Inert & 1 \\
\hline 2. Location & NPA $^{1}$ and UWR & 3 \\
& NPA or UWR & 2 \\
& No NPA or UWR & 1 \\
\hline \multirow{2}{*}{ 3. Key minerals for economy } & On the list & 3 \\
& Not on the list & 1 \\
\hline \multirow{3}{*}{ 4. Amount of waste } & $>100,000 \mathrm{Mg}$ & 3 \\
& $50,001-100,000 \mathrm{Mg}$ & 2 \\
\hline 5. Clay minerals present & $10,001-50,000 \mathrm{Mg}$ & 1 \\
\hline 6. Sources of potassium & Yes & 3 \\
present & No & 1 \\
\hline 7. Sources of magnesium & Yes & 3 \\
present & No & 1 \\
\hline
\end{tabular}

${ }^{1}$ Nature protection area, ${ }^{2}$ Underground water reservoir.

Step 4 involved the construction of a pairwise comparison matrix to determine the relative importance of each criterion according to the Analytical Hierarchy Process (AHP) methodology proposed by Saaty [22]. The AHP procedure has been applied in a wide range of different decision making problems such as: selection, evaluation, benefit-cost analysis, allocations, planning and development, priority and ranking, and decision-making. A review of these applications has been done for example by Vaidya and Kumar [23]. With respect to mining-related problems, noteworthy AHP applications include [24-29]. Dey and Ramcharan [24] proposed an AHP based analytical framework for site selection for the expansion of a limestone quarry operation, Ptak [25] employed AHP to construct an evaluation method for the assessment of rock mineral deposits whose development could affect Nature 2000 areas, Gupta and Kumar [26] examined the application of AHP for the selection of an appropriate stoping method for mining underground ore deposit, Sobczyk and Badera [27] studied the possibilities of predicting which of the specified hard coal deposits are relatively less contentious with regard to local economic, social and environmental determinants, Blachowski [28] used AHP in combination with GIS to assess the accessibility of a brown coal deposit for development with respect to environmental and land use functions, and Malinowska and Matonóg [29] tried to estimate the sinkhole hazard in former and present mining areas with AHP.

In our study, we employed the AHP methodology to determine the weights of criteria based on feedback provided by the 4 authors and 4 additional experts representing the following specializations: spatial planning, environmental protection, resource management and mining administration. 
The experts are active in regional authorities and institutions such as: Institute for Territorial Development, District Mining Office, Regional Inspectorate of Environmental Protection and Wroclaw University of Science and Technology. We used the template developed by Goepel [30].

If $n$ is the number of analysed criteria, then the AHP comparison procedure is as follows:

- $\quad$ to construct a $n \times n$ pairwise comparison matrix $m$ for analysed criteria, where $a_{i j}$ denotes entry in the $i$ th row and the $j$ th column of matrix $m$,

- $\quad a_{i j}$ states the preference score of criterion $i$ to criterion $j$ using the nine-integer value scale suggested by Saaty [31], where:

1 denotes that criteria $i$ and $j$ are of equal importance,

3 is moderate importance of $i$ over $j$,

5 is strong importance of $i$ over $j$,

7 is very strong importance of $i$ over $j$,

9 denotes that criterion $i$ is extremely more important than criterion $j$, and

$2,4,6$, and 8 are intermediate, optional, values.

- $\quad$ the entries of preference score $a_{i j}$ and $a_{j i}$ must satisfy the following constraint of Equation (1):

$$
a_{i j} \times a_{j i}=1
$$

- $\quad$ to establish a normalized pairwise comparison matrix $m$, the sum of each column must be equal to 1 . This can be obtained using Equation (2) to calculate $\bar{a}_{i j}$ for each entry of the matrix $\bar{m}$,

$$
\overline{\mathrm{a}_{i j}}=\frac{a_{i j}}{\sum_{l=1}^{n} a_{i j}}
$$

- $\quad$ to obtain the relative weights, the average across rows is computed using Equation (3); for each element, the relative weight is within the range of 0 to 1 and a higher weight shows a greater influence of a given element (criterion),

$$
w_{i}=\frac{\sum_{l=1}^{n} \overline{a_{i j}}}{n}
$$

A test of the degree of consistency of the derived weights is performed to check consistency of the experts' judgements. It involves a calculation of the Consistency Ratio (CR), which indicates the probability that the matrix values have been randomly generated. According to Saaty [22], a matrix that has a consistency ratio greater than 0.10 should be re-evaluated.

For controlling the consistency of the estimated weight values, the consistency ratio (CR) is calculated as follows:

- calculate the eigenvector and the maximum eigenvalue for matrix $m$,

- next, calculate an approximation to the Consistency Index (CI) according to Equation (4):

$$
C I=\frac{\lambda_{\max }-n}{n-1}
$$

where,

- $\quad \lambda_{\max }$ is the maximum eigenvalue of the comparison matrix,

- $\quad n$ is the number of criteria. The Consistency Ratio is calculated from Equation (5),

$$
C R=\frac{C I,}{R I}
$$


where,

- $\quad R I$ is the random consistency index that varies according to the number of criteria in a comparison $(n)$.

As mentioned above for $C R \leq 0.10$, the degree of consistency is considered satisfactory; otherwise, there are serious inconsistencies in the pairwise comparison and the AHP may not return meaningful results.

Once the weights are calculated, they are used to determine the final weighted score of each mining waste site as a sum of products (step 5) in Equation (6):

$$
S=\sum_{i=1}^{n} C_{i} \times w_{i}
$$

Then, in the last step (6) a ranking list was made according to the individual score of each mining site.

\section{Results}

\subsection{Results of Quantitative Analysis}

The quantitative analysis showed that the total amount of all types of mining waste in the years 2010-2016 amounts to 6,182,277 Mg. This waste was generated in 18 (out of 26) poviats of the Lower Silesia region. The spatial distribution of the deposited waste is shown graphically on a map in Figure 3. Waste generated during the extraction of minerals from deposits constitutes $46.95 \%$ of the total waste generated in the analysed period. Meanwhile, the remaining $53.05 \%$ consists of waste created in the course of processing these minerals. The volume of mining waste produced year by year is shown in Figure 4.

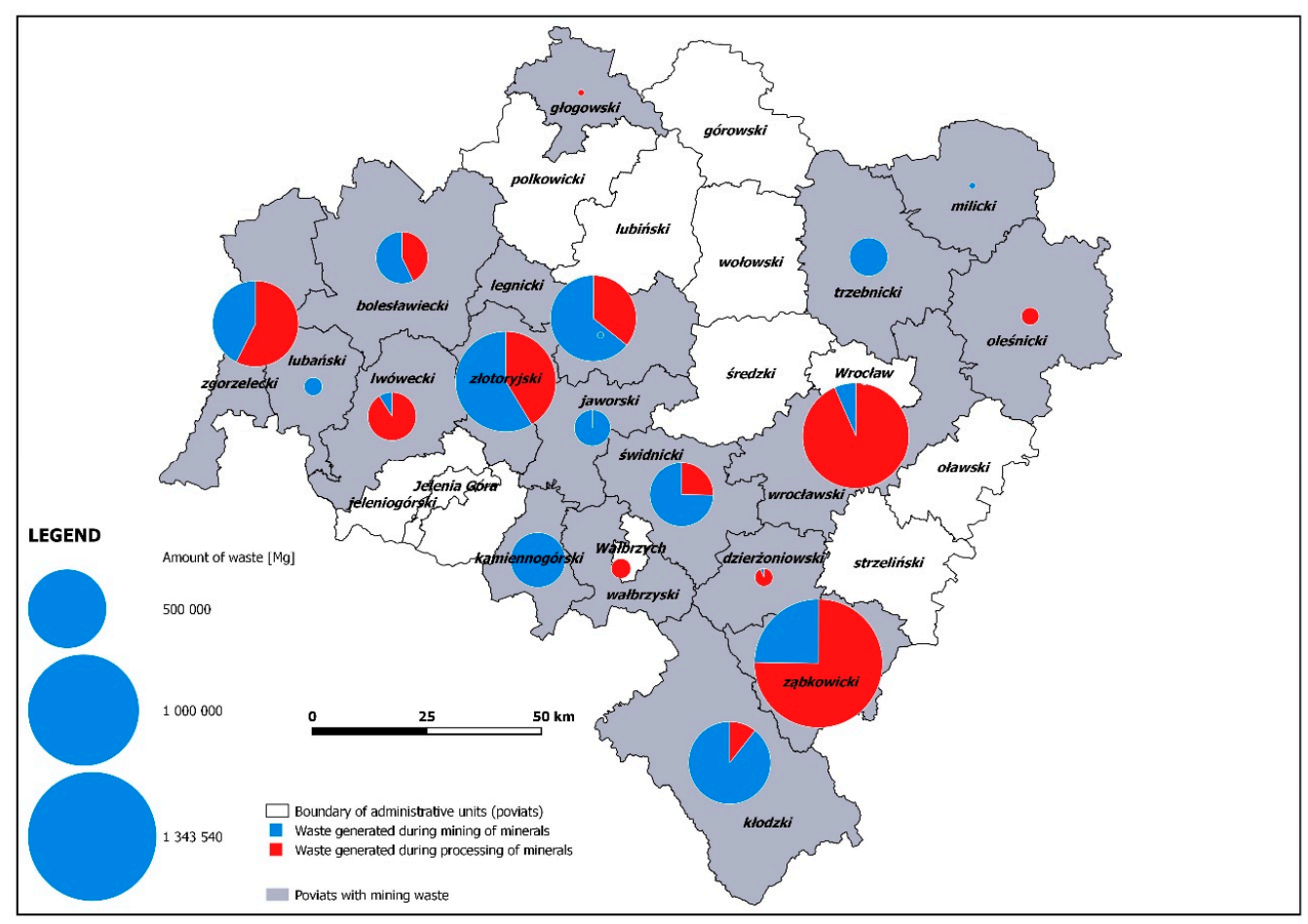

Figure 3. Waste generated in the mining of rock raw materials in the Lower Silesia region, classified by type of waste, in the years 2010-2016 [Mg]. 


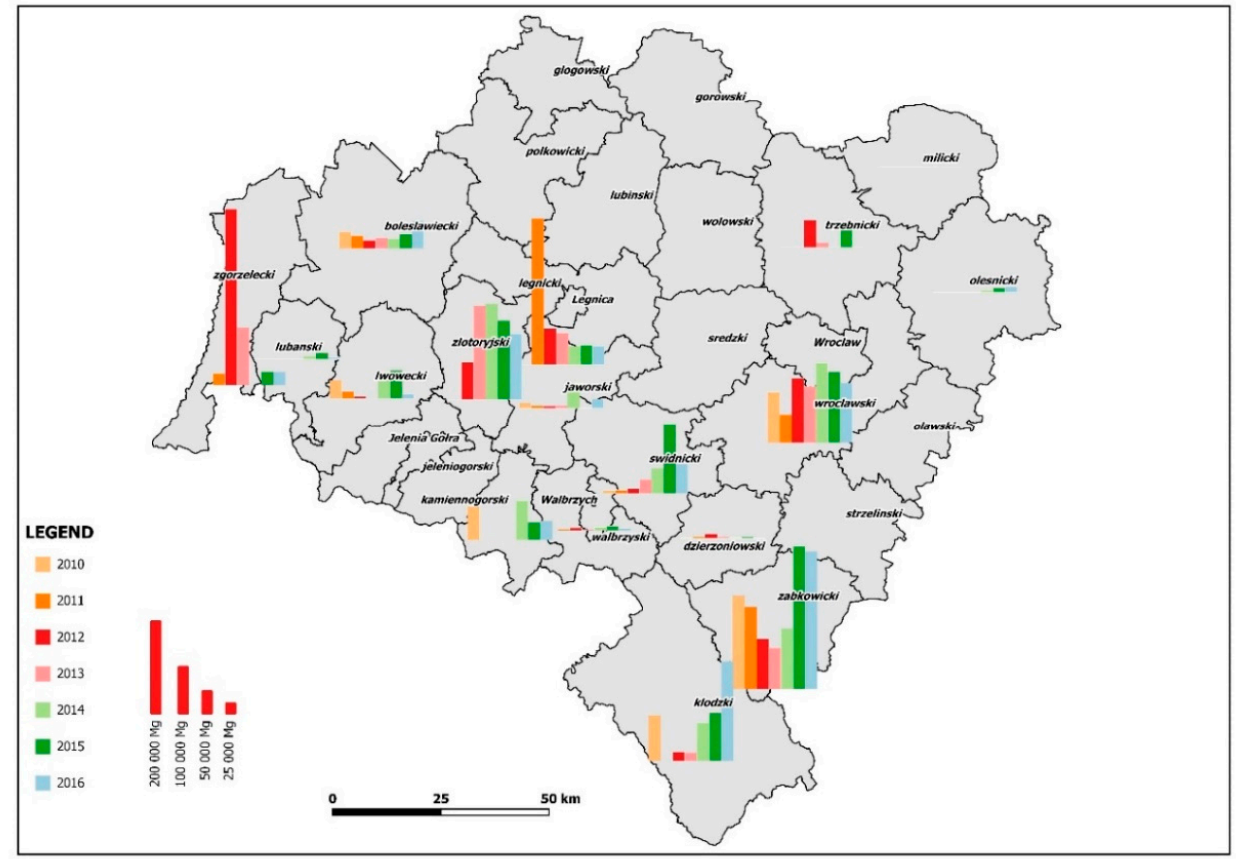

Figure 4. Waste generated in rock mineral mining year by year (2010-2016) in administrative units of the Lower Silesia Province [Mg].

Figure 5 presents mining waste generated in the mining of three main rock mineral groups in Lower Silesia, that is: dimension and crushed stones, sands and gravels, and other rock minerals.

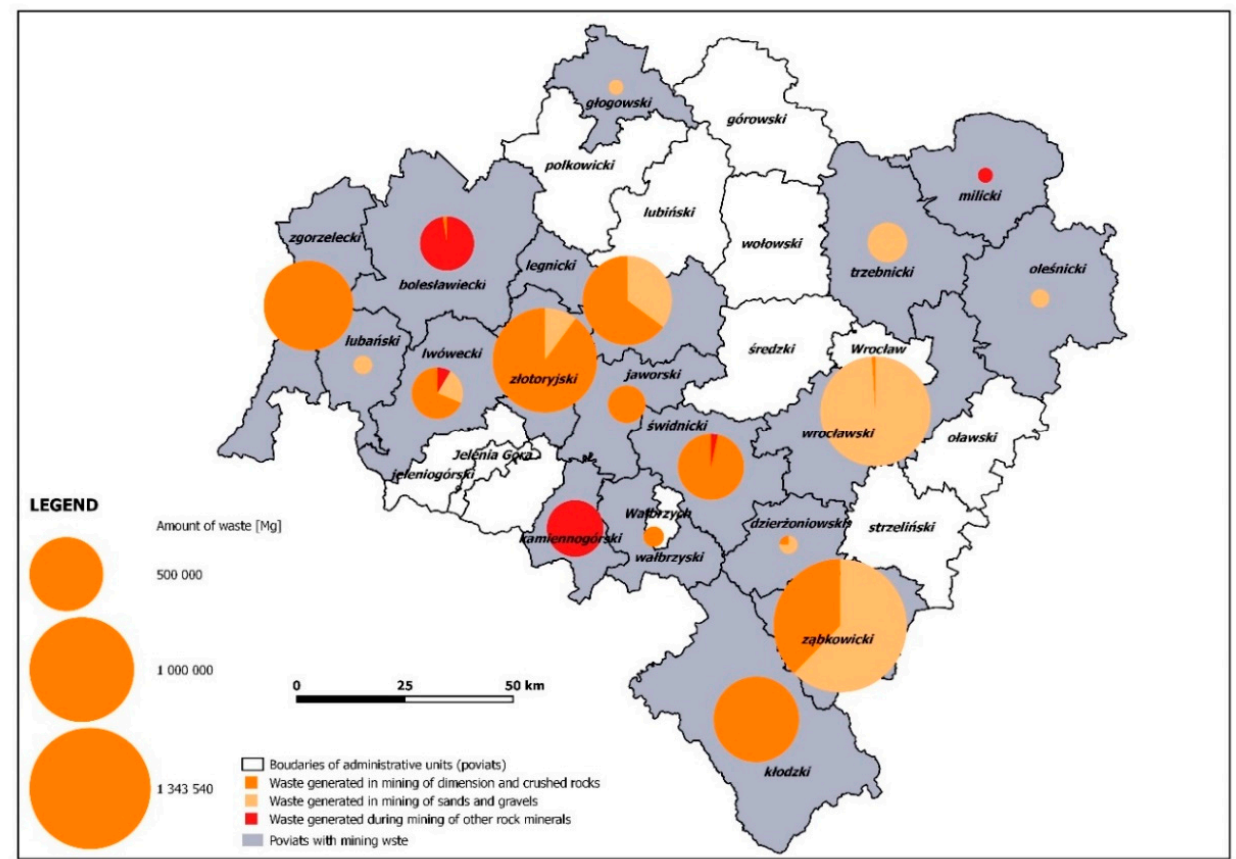

Figure 5. Mining waste generated in the mining and processing of the three main groups of rock minerals in Lower Silesia: dimension and crushed rocks, sands and gravels and other rock minerals $[\mathrm{Mg}]$.

The graph (Figure 6) shows temporal changes, as well as the variation in the composition of generated mining waste from 2010 to 2016. 


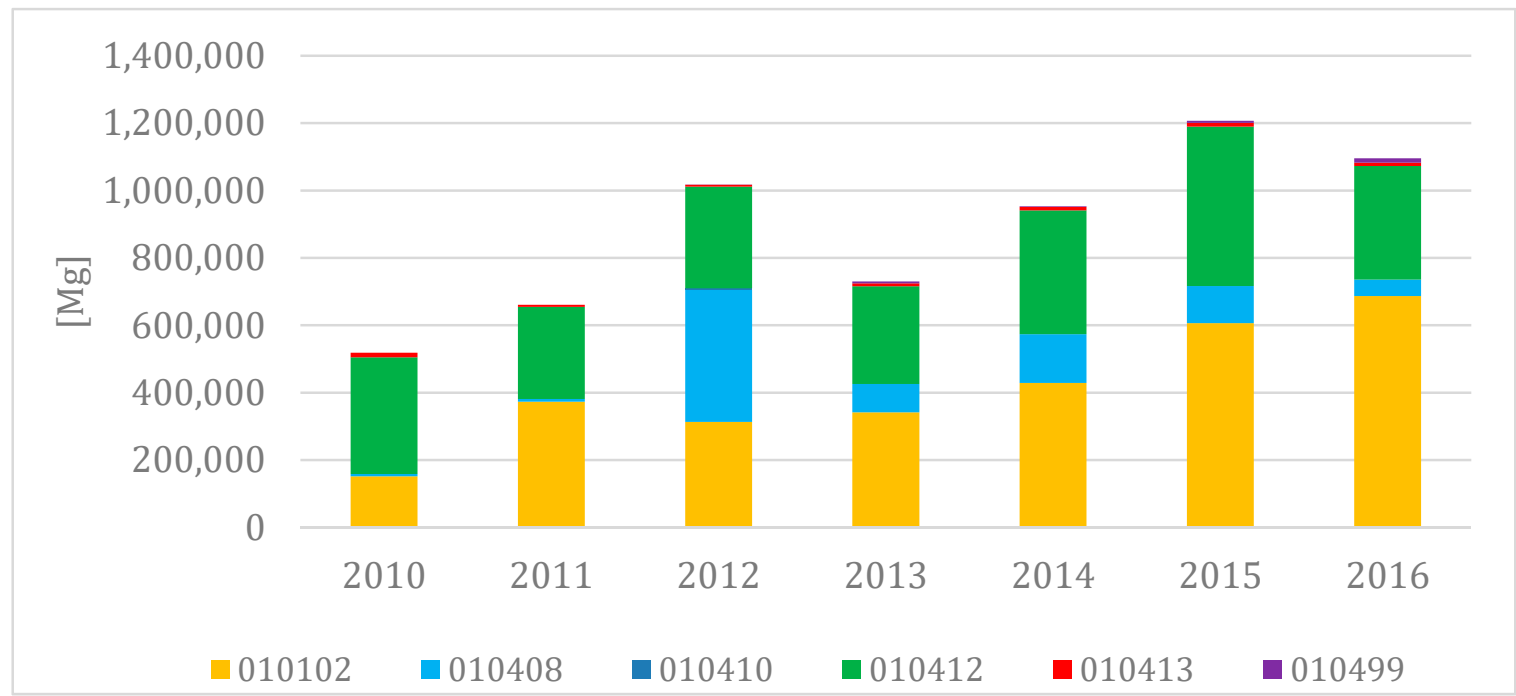

Figure 6. Mining waste types produced in rock mineral mining in the Lower Silesia Province in 2010-2016 [Mg]: 010102-mining waste; 010408-processing waste (gravels and crushed rocks); 010410 - processing waste in the form of dusts and powders; 010412—waste generated during the flushing and cleaning of rock minerals; 010413-waste generated during cutting and processing of rocks; and 010499—other waste from the processing of rock minerals.

\subsection{Results of Qualitative Analysis}

The verified significance of the criteria adopted for the quantitative multi-criteria analysis is shown in Table 2. The most important criteria as determined by the input provided by the multidisciplinary group of experts are: location within boundaries of protected areas (27.3\%) and key minerals for national economy $(20.6 \%)$. Four other criteria $(4,5,6$, and 7$)$ obtained similar weights ranging from $10.8 \%$ to $12.2 \%$. The "type of waste" criterion was regarded as the least significant.

Table 2. Weights of criteria.

\begin{tabular}{cc}
\hline Criterion (No./Name) & Weight (\%) \\
\hline 1. Type of waste & 6.5 \\
2. Location in protected areas & 27.3 \\
3. Key minerals for economy & 20.6 \\
4. Amount of waste & 10.8 \\
5. Clay minerals present & 12.2 \\
6. Sources of potassium present & 10.8 \\
7. Sources of magnesium present & 11.8 \\
\hline
\end{tabular}

In the case of 7 criteria $(n=7)$, the Random Index (RI) equals to 1.32 and the Consistency Ratio (CR) is $1.2 \%$, which is within the accepted limits. The consensus of experts equals $55 \%$.

An example of calculating the final weighted score for a given mining site is shown in Table 3. Table 4 contains the final ranking of analysed mines. The scores ranged from 2.6542 to 1.4892 . The highest possible theoretical value was 3 . 
Table 3. Sample procedure for calculating the final weighted score (Grabina Ślaska-Kam.15/27 site).

\begin{tabular}{ccccc}
\hline \multicolumn{5}{c}{ Mine Site Name: Grabina Śląska-Kam. 15/27, Location: Swidnicki Poviat } \\
\hline \multirow{2}{*}{ Criterion } & Assigned Score (Ci) & Weight (wi) & Product (Ci $\times$ wi) & $\begin{array}{r}\text { Sum of Products } \\
\text { (Weighted Score) }\end{array}$ \\
\cline { 2 - 3 } C1 & 1 & 0.0645 & 0.0645 & \\
C2 & 1 & 0.2734 & 0.2734 & \\
C3 & 3 & 0.2065 & 0.6195 & 2.0890 \\
C4 & 3 & 0.1079 & 0.3237 & \\
C5 & 3 & 0.1217 & 0.3651 & \\
C6 & 3 & 0.1084 & 0.3252 & \\
C7 & 1 & 0.1176 & 0.1176 & \\
\hline
\end{tabular}

Table 4. Ranking of mining waste sites*.

\begin{tabular}{|c|c|c|c|c|}
\hline Rank & Mining Site & Mineral & Location & Weighted Score \\
\hline 1 & Krzeniów & basalt & złotoryjski & 2.6542 \\
\hline 2 & Lubień & basalt & legnicki & 2.3808 \\
\hline 3 & Grabina Śląska-Kam. 15/27 & granite & świdnicki & 2.0890 \\
\hline 4 & Gniewków & granite & świdnicki & 1.9811 \\
\hline 5 & Boguszyce & sands and gravels & oleśnicki & 1.9298 \\
\hline 6 & Romanowo Górne & marble & kłodzki & 1.9022 \\
\hline 7 & Rogoźnica II & granite & świdnicki & 1.8732 \\
\hline 8 & Byczeń I & sands and gravels & ząbkowicki & 1.8722 \\
\hline 9 & Stróża Górna II & sands and gravels & wrocławski & 1.8722 \\
\hline 10 & Sulików & basalt & zgorzelecki & 1.8640 \\
\hline 11 & Słupiec-Dębówka & gabbro & kłodzki & 1.8640 \\
\hline 12 & Janina I & sandstone & bolesławiecki & 1.7326 \\
\hline 13 & Rybnica Leśna & melaphyre & wałbrzyski & 1.6864 \\
\hline 14 & Doboszowice I & gneiss & ząbkowicki & 1.6564 \\
\hline 15 & Radostów Średni II, III & sands and gravels & jaworski & 1.6564 \\
\hline 16 & Braszowice & gabbro & ząbkowicki & 1.6482 \\
\hline 17 & Jenków & schist & jaworski & 1.5209 \\
\hline 18 & Nowy Waliszów-soczewka C & marble & kłodzki & 1.5168 \\
\hline 19 & Połom & limestone & złotoryjski & 1.5168 \\
\hline 20 & Rędziny & dolomite & kamiennogórski & 1.4892 \\
\hline
\end{tabular}

* In Table 4 , the bold fonts indicate the 6 highest rated mining waste sites.

\section{Discussion}

\subsection{Analysis of Mining Waste Quantity}

The quantitative analysis of the extraction waste in the years 2010-2016 showed variability from year to year. The variation in waste generation varies from $518,792.89 \mathrm{Mg}$ in 2010 to $1,206,708.17 \mathrm{Mg}$ in 2015 (Figure 6). Results of the calculations indicated that the generation of extraction waste is increasing systematically in the region. Since 2010, it has more than doubled. Until 2012, it might have been caused by the preparation of Poland for the Euro 2012 event, which caused an increase of road and construction investments. Moreover, the high development dynamics was achieved by companies manufacturing stone products for sports, hotel and other facilities which accompanied the advent of Euro 2012. The subsequent growth in waste generation in 2014 and 2015 was caused by the increase in road and building construction investments compared to the previous year.

\subsection{Analysis of Mining Waste Quality}

A qualitative analysis was carried out in two areas: environmental and economic. On the environmental level, the onerousness of waste (inert and hazardous waste) was analysed, as well as the location of the waste neutralization facility in areas of protected environment (e.g., landscape parks or their buffer zones, areas of protected landscape, NATURE 2000 areas, Main Underground Water 
Reservoirs, etc.). Meanwhile, on the economic level, the analysis concerned: the type of generated waste, waste having a potential economic significance for the industry, the quantity of waste and the set of key raw materials for the Polish economy. The types of generated waste were:

- $\quad$ waste from mining of minerals other than metal ores, and these mainly consisted of overburden masses containing clay raw materials,

- waste from gravel and crushed rocks,

- waste in the form of dusts and powders,

- waste generated during the rinsing and cleaning of minerals,

- $\quad$ waste generated during the cutting and processing of rocks.

Mining waste that occurs in appropriate quantities (above 10,000 Mg) and has a composition that can be potentially used, has a potential economic significance that can be applied within the industry. Equally significant is the list of raw materials crucial for the Polish economy developed by [8]. Therefore, this set of key raw materials was analysed, along with potential possibilities for using waste located in the considered waste neutralization facilities. The research took into account the possibilities of using clay raw materials, but also using waste materials as a source of potassium (e.g., dusts and small granite fractions) or magnesium (e.g., serpentinite, basalt, and syenite). This was based on the literature analysing potential uses, which indicated the most promising applications in the industry or agriculture [9-21,32]. Therefore, the results of the qualitative multicriteria analysis indicated 6 mining waste neutralization facilities (highest scores in Table 4) with waste materials, which may find use by applying known or new technologies. These facilities concern the exploitation of the following deposits: Krzeniów (basalt), Lubień (basalt), Grabina Śląska Kam. 15/27 (granite), Gniewków (granite) and Boguszyce (sands and gravels). The selected facilities contain waste consisting of: clay, gangue with overgrowths of weathered granite, basalt, weathered granite, granite, and overburden containing clay raw materials (Table 5).

Table 5. Potential possibilities for using waste located in the selected facilities.

\begin{tabular}{|c|c|c|}
\hline $\begin{array}{c}\text { Name of the Mining } \\
\text { Plant }\end{array}$ & Waste & Potential Use \\
\hline Krzeniów & $\begin{array}{l}\text { gangue with overgrowths } \\
\text { of weathered basalt } \\
\text { Basalt-fraction } 0-8 \mathrm{~mm}\end{array}$ & rock (basalt meal) for improvement of soil properties \\
\hline Lubień & clay & $\begin{array}{l}\text { use of bentonite for soil fertilization } \\
\text { sorbent-fertilizer of montmorillonite rocks for } \\
\text { reclamation } \\
\text { use of bentonite clay in the food industry (for storing } \\
\text { fruits and vegetables) } \\
\text { use of kaolin as a feed additive }\end{array}$ \\
\hline \multirow[t]{2}{*}{$\begin{array}{c}\text { Grabina Śląska-Kam. } \\
15 / 27\end{array}$} & clay & $\begin{array}{l}\text { use of bentonite for soil fertilization } \\
\text { sorbent-fertilizer of montmorillonite rocks for } \\
\text { reclamation } \\
\text { use of bentonite clay in the food industry (for storing } \\
\text { fruits and vegetables) } \\
\text { use of kaolin as a feed additive }\end{array}$ \\
\hline & weathered granite & $\begin{array}{l}\text { granite rock meal-for improvement of soil properties } \\
\text { for the manufacture of aggregates of the inferior quality } \\
\text { for the manufacture of hydro-technical stones } \\
\text { for the manufacture of light aggregates }\end{array}$ \\
\hline
\end{tabular}


Table 5. Cont.

\begin{tabular}{|c|c|c|}
\hline $\begin{array}{l}\text { Name of the Mining } \\
\text { Plant }\end{array}$ & Waste & Potential Use \\
\hline \multirow[t]{2}{*}{ Gniewków } & clay & $\begin{array}{l}\text { use of bentonite for soil fertilization } \\
\text { sorbent-fertilizer of montmorillonite rocks for } \\
\text { reclamation } \\
\text { use of bentonite clay in the food industry (for storing } \\
\text { fruits and vegetables) } \\
\text { use of kaolin as a feed additive }\end{array}$ \\
\hline & granite saprolite & $\begin{array}{l}\text { granite rock meal—for improvement of soil properties } \\
\text { for the manufacture of light aggregates }\end{array}$ \\
\hline Boguszyce & clay & $\begin{array}{l}\text { use of bentonite for soil fertilization } \\
\text { sorbent-fertilizer of montmorillonite rocks for } \\
\text { reclamation } \\
\text { use of bentonite clay in the food industry (for storing } \\
\text { fruits and vegetables) } \\
\text { use of kaolin as a feed additive }\end{array}$ \\
\hline Romanowo Górne & overburden & $\begin{array}{l}\text { use of bentonite for soil fertilizations } \\
\text { orbent-fertilizer of montmorillonite rocks for reclamation } \\
\text { use of bentonite clay in the food industry (for storing } \\
\text { fruits and vegetables) } \\
\text { use of kaolin as a feed additive }\end{array}$ \\
\hline
\end{tabular}

\subsection{Potential Uses of Mining Waste in Selected Facilities}

The possibilities of waste management in selected facilities containing clay raw materials concern waste consisting mainly of clay minerals, such as: kaolinite, montmorillonite and other silicates, as well as quartz, apatite, granites or iron hydroxide. These raw materials, due to their specific properties, e.g., high capillarity, unique rheological properties, hardening, plasticity, high swelling ratio, may be widely used in various branches of industry. One potential application is the use of montmorillonite rocks for the manufacture of sorbent-fertilizers used for the reclamation of lands after the exploitation of sands [9]. This solution was covered by the patent PRL No. 53762 of 1964 [33] and supplemented by the patent PRL 53142 of 1965 [34]. The montmorillonite rocks, which include bentonites and bentonite clays, are characterized by a high content of montmorillonite, which is a material that swells in the presence of water and has a high sorption capacity. One application of bentonite management is to use it for the manufacture of paraffin-bentonite composites. Results of research showed that the rate of heat exchange increased thanks to the use of bentonite. This material may also be used in soil fertilization, due to its moisture-retaining properties and slow release of fertilizing elements. Due to that fact, bentonite provides greater flexibility and improved strength of soils, as well as better water impermeability. Another potential application is the use of bentonite in pesticide production. It is used to increase effectiveness through the reversible binding of pesticides on the bentonite. It is inert and it does not have a harmful impact on the branches, and it can build nutrients for insects $[10,11]$. Due to the fact that one of the properties of clay is adsorption and the ability to interact with metal ions, it can be used to remove heavy metal ions and purify industrial and drinking water. Metal cations interact with clay, and adsorption takes place due to ion exchange and the precipitation of hydroxide on the clay surface. Moreover, clay contains organic matter, which can form complexes with metals from the surrounding medium $[10,11,13]$. In order to reduce the level of pesticides, leaching is proposed in an environment such as air and water-one of the possible solutions is the reversible binding of pesticides on clay minerals. Many studies focus on the adsorption of pesticides from clay minerals to remove them from the water $[12,14]$. Bentonite clay may also be used as a more effective method for storing fruits and vegetables in households, instead of storing them in warehouses and cold stores [17]. Kaolinite may be successfully used in the manufacture of feed additives. Research in the area of 
feeding broilers and breeding laying hens indicates that the addition of aluminosilicates, such as kaolin of the FKW type or zeolite of the A type, to the feeds has a positive effect on the production rates, as well as on the quality of egg shells. A solution for the feed additives for poultry, particularly broiler chickens and forest hens, has been covered by the patent PL 172908 of 1994 [35].

Rock raw materials rich in calcium, potassium and magnesium can be successfully used as rock meals. They are created as a result of grinding the given rock. The idea of using basalt meals comes from the observation that alkaline and inert vulcanites are the basis for the formation of perfect, fertile soils. The supply of basalt to depleted soil, in a form that is both easy for chemical distribution and dusty, results in a comprehensive "remineralisation" of the soil substrate. In addition, basalt meals are often described as an element that improves the soil properties due to its relatively low mineral content. Clearly emphasized advantages of meals include their non-toxicity, the fact that overdosing is impossible, non-leaching by groundwater and the fact that they have neither a shelf-life nor a maximum storage period. The advantageous feature of basalt meals is their varied chemical composition, concerning both main oxides and trace elements [13,36]. Meanwhile, granite meals are useful in heavy soils, as well as light and sandy soils, with a low content of clay minerals. These meals increase the water capacity, particularly in the humus layer. The most important advantage of these meals is the content of many necessary macro, micro and ultra-micronutrients. In addition, they play a sanitary role, preventing the spread of diseases and pests. They also retain nitrogen in the soil. Granite meals are best suited for growing plants that like acidic soil, such as azaleas, bilberries, blueberries, cranberries and rhododendrons. The serpentinite meal is rich in hydrated magnesium silicates. This meal can also provide soils with many micronutrients, the most important being iron and phosphorus [32]. Rock silica meal, originating from the selected groups of basalt, granite, serpentinite and amphibolite meals, may be used for the manufacture of granulate supporting the cultivation of plants. Such a granulate remains on the soil in unchanged form until the moment of atmospheric precipitation, after which, it gradually disintegrates and returns to a dusty form as a result of the impact of the atmospheric moisture, penetrating into the soil structure. Such a granulate is completely non-toxic; it does not lose its properties, has no shelf-life and cannot be overdosed. The method of manufacture for this granulate has been covered by the patent PL 210673 filed in 2009 [37].

It is also worth noting that granite waste can be used for the production of light aggregates. The Institute of Mechanization of the Construction and Rock Mining in Poland has developed a technology for the use of granite waste for the manufacture of light artificial aggregates. In the developed technology, the previously used mineral raw materials have been replaced with granite waste. The degree of replacement ranged from $30 \%$ to $100 \%$. The results of conducted studies turned out to be very beneficial, because the strength of the obtained aggregates is 1.5 times higher than aggregates manufactured only with the use of silica. Moreover, the use of granite waste led to the total elimination of the flux, which simplifies the production process [16]. Another possibility is the use of granite waste for the manufacture of hydro-technical aggregates, which may have various fractions.

In addition, there are many studies carried out in Poland concerning the use of extraction waste generated in Lower Silesia. At the Faculty of Geoengineering, Mining and Geology of the Wroclaw University of Science and Technology, research is conducted regarding the use of clay raw materials in agriculture as an additive to feeds, mineral fertilizers or sorbents eliminating odour onerousness. Meanwhile, at the Faculty of Chemistry, research was conducted regarding the use of powdered gabbro for the manufacture of thermoplastic composites with good thermal and mechanical properties. The results of the research that was carried out proved that the powdered gabbro has a greater impact on the increase in stiffness of the composites and results in composites with a higher tensile strength than those created with the use of $\mathrm{CaCO}_{3}$ [18]. Other research concerned the use of accompanying minerals as components for the construction of hydro-insulating screens from selected deposits located in Poland. The results showed that none of the studied samples meets all the requirements that must be fulfilled by components used for the construction of hydro-insulating screens. Nevertheless, some of 
the accompanying minerals that were studied could be used for widely understood environmental protection, maybe as mineral sorbents [21]. In 2010, a study was conducted regarding the dusty basalt fractions. An analysis was carried out on these fractions focusing on their use in covering freshly formed asphalt surfaces, in the agricultural domain and in the ceramic industry, as an additive for dyeing glass or for the production of clinker ceramic products $[9,15,20]$.

\section{Conclusions}

The use of mining waste is a challenging and growing problem, especially in regions with large mining industry shares in the economy and with significant nature and landscape qualities. Lower Silesia is a region with a large share of protected areas, and (as the study found out) with a problem relating to large volumes of waste generated during rock mineral mining. The province is the largest dimension and crushed stones producer in Poland. In addition, because of the circular economy context it is important to find solutions that would allow an industrial or other use of this kind of waste.

The study focused on the problem of rock mineral mining and proposed a set of 7 criteria, economic and environmental, for the assessment of the potential industrial use of waste from rock mineral mines.

The adopted qualitative multi-criteria analysis methodology, based on the AHP, along with a weighted scoring procedure, provided information on the potential of particular mining waste sites to be developed in the province. 20 such sites were selected and indicated as having such potential based on the study of waste composition. Six of these were indicated as the most promising for the reuse of mining waste generated during the mining and processing of rock minerals. These include two granite mines, two basalt mines and one sand and gravel mine, as well as one marble mine. The characteristics of mining waste in these sites have been studied, and potential uses have been indicated. These include fertilisation and soil improvement, the manufacture of sorbent-fertilizers, the use for storing household fruits and vegetables or of storing feed additives, and the manufacture of light aggregates or aggregates of an inferior quality.

This is one of the first studies to analyse the state of the mining waste production while focusing on an entire mining region (Lower Silesia Province). The GIS based quantitative analysis provided information on the spatial and temporal distribution of the mining waste produced. The results of the quantitative study and spatial distribution of mining waste, along with the results of the qualitative study, provide information for regional authorities and actors aiming at reducing the environmental burden of waste.

The proposed methodology is a contribution for studies on the industrial potential of mining waste, and it will have an effect on the regional development policy in Lower Silesia. The methodology could also be tested in other regions with significant mining waste problems.

Author Contributions: Conceptualization: U.K. and J.B.; Methodology: U.K., J.B. and H.W.; Software, J.B. and J.G.Z.; Validation, U.K., J.B. and J.G.Z.; Formal Analysis, U.K. and J.B.; Investigation, J.G.Z., U.K. and J.B.; Resources, J.G.Z. and U.K.; Data Curation, J.B. and J.G.Z.; Writing-Original Draft Preparation, U.K., J.B. and J.G.Z.; Writing-Review \& Editing, J.B., U.K., J.G.Z.; Visualization, J.B.; Supervision, U.K. and J.B.; Project Administration, J.B. and U.K.; Funding Acquisition, Marshal Office of Lower Silesia.

Funding: This research has been funded from the European Regions Toward Circular Economy (CircE) project co-financed from the European Regional Development Fund, Interreg Europe Programme and from the research project No. 0401/0123/2017 Research on natural and anthropogenic environmental changes using geographic information technology.

Acknowledgments: The authors would like to thank institutions listed in the paper for providing essential data and assistance as well as experts participating in multi-criteria analysis.

Conflicts of Interest: The authors declare no conflict of interest. 


\section{References}

1. Hudson-Edwards, K.A.; Jamieson, H.E.; Lottermoser, B.G. Mine wastes: Past, present, future. Elements 2011, 7, 375-380. [CrossRef]

2. Lottemorser, B.G. Recycling, reuse and rehabilitation of mine wastes. Elements 2011, 7, 405-410. [CrossRef]

3. Jamieson, H.E.; Walker, S.R.; Parsons, M.B. Mineralogical characterization of mine waste. Appl. Geochem. 2015, 57, 85-105. [CrossRef]

4. Gorakhki, M.H.; Barether, C.A. Sustainable reuse of mine tailing and waste rock as water-balance cover. Minerals 2017, 7, 128. [CrossRef]

5. Santibañez, C.; Fuente, M.; Bustamente, E.; Silva, S.; León-Libos, R.; Ginocchio, R. Potential use of organic-and hard-rock mine wastes on aided phytostabilization of large-scale mine tailings under semiarid mediterranean climatic conditions: Short-term field study. Appl. Environ. Soil Sci. 2012, 1-15. [CrossRef]

6. Kaźmierczak, U.; Kaźmierczak, W. Assessment Lower Silesian rock in the years 2003-2011. Min. Sci. 2012, 134, 143-152. (In Polish)

7. Brzezinski, D.; Miskiewicz, W. Dimension and crushed stone. In Balance of Mineral Deposits in Poland as of 31 XII 2017; Szuflicki, M., Malon, A., Tyminski, M., Eds.; Polish Geological Institute-National Research Institute: Warsaw, Poland, 2018; pp. 99-121. (In Polish)

8. Radwanek-Bąk, B.; Galos, K.; Nieć, M. Pivotal, strategic and critical mineral raw materials for the Polish economy. Geol. Rev. 2018, 66, 153-159. (In Polish)

9. Bolewski, A.; Skawina, T. An Attempt to Use Montmorillonite Rocks for the Reclamation of Sands; Polish Academy of Sciences Branch in Krakow, Commission of Mineralogical Sciences, Geological Publishers: Warszawa, Poland, 1972; pp. 1-68. (In Polish)

10. Wesley, L.R. Clays and Clay Minerals: Geological Origin, Mechanical Properties and Industrial Applications; Nova Science Publishers: Hauppauge, NY, USA, 2014; p. 465.

11. Savic, I.; Stojiljkovic, S.; Savic, S.; Gajic, D. Industrial application of clays and clay minerals. In Clays and Clay Minerals: Geological Origin, Mechanical Properties and Industrial Applications; Wesley, L.R., Ed.; Nova Science Publishers: Hauppauge, NY, USA, 2014; pp. 379-402.

12. Donia, A.M.; Atia, A.A.; Hussien, R.A.; Rashad, R.T. Comparative study on the adsorption of malathion pesticide by different adsorbents from aqueous solution. Desalin. Water Treat. 2012, 47, 300-309. [CrossRef]

13. Kłapyta, Z. Montmorillonite rocks of the upper silesian coal basin. In Mineral Polish Sorbents; Kłapyła, Z., Żabiński, W., Eds.; Uczelnianie Wydawnictwa Naukowo-Dydaktyczne: Kraków, Poland, 2008; pp. 20-30, (In Polish). ISBN 9788374641074.

14. Chevillard, A.; Angellier-Coussy, H.; Peyron, S.; Gontard, N.; Gastaldi, E. Investigating ethofumesate-Clay interactions for pesticide controlled release. Soil Sci. Soc. Am. J. 2012, 76, 420-431. [CrossRef]

15. Zagożdżon, P.P. Basalt powder in agricultural use. Min. Sci. 2008, 123, 133-142. (In Polish)

16. Kukielska, D.; Cebra, P. Development of granite waste. Miner. Aggreg. 2018, 2, 93-97. (In Polish)

17. Al-Arfaj, A.A.; Murugan, A.M.; Chinnathambi, A.; Al-Hazmi, M.I. Cost-effective bentonite clayed pyramid technologies for household fruits and vegetables siorage. J. Food Agri. Environ. 2013, 11, 175-180.

18. Czycz, D.; Kędziora, G.; Steller, R.; Pigłowski, J.; Pawlaczyk, S.; Poderski, R.; Dębiński, K. Properties of thermoplastics filled with powder of igneous rock Gabro. In Proceedings of the European Advanced Materials Congress, Stockholm, Sweden, 22-24 August 2017; Proceedings and Abstracts Book. pp. 410-411.

19. Nowak, A. Technologies of processing of rock mineral waste. J. Polish Miner. Eng. Soc. 2002, S1, 57-68. (In Polish)

20. Gacki, F.; Feliks, J.; Wyszomirski, P. Research on possible application of waste basaltic dust. Eng. Chem. Apparatus 2013, 3, 174-175. (In Polish)

21. Bożęcki, P.; Rzepa, G. The possibility of using of accompanying mineral deposits from selected polish rock raw materials as components for hydro-isolation layer. Sur. Min. 2012, 53, 104-108. (In Polish)

22. Saaty, T.L. The Analytic Hierarchy Process; McGraw-Hill: New York, NY, USA, 1980.

23. Vaidya, O.S.; Kumar, S. Analytic hierarchy process: An overview of applications. Eur. J. Oper. Res. 2006, 169, 1-29. [CrossRef]

24. Dey, P.K.; Ramcharan, E.K. Analytic hierarchy process helps select site for limestone quarry expansion in Barbados. J. Environ. Manag. 2008, 88, 1384-1395. [CrossRef] [PubMed] 
25. Ptak, M. The natural elements of the deposit classification method in nature 2000 Sites-Kzn2000/mAHP. Min. Sci. 2012, 134, 241-251. (In Polish)

26. Gupta, S.; Kumar, U. An analytical hierarchy process (AHP)-guided decision model for underground mining method selection. Int. J. Min. Reclam. Environ. 2012, 26, 324-336. [CrossRef]

27. Sobczyk, E.; Badera, J. The problem of developing prospective hard coal deposits from the point of view of social and environmental conflicts with the use of AHP method. Miner. Resour. Manag. 2013, 29, 5-24. [CrossRef]

28. Blachowski, J. Methodology for assessment of the accessibility of a brown coal deposit with analytical hierarchy process and weighted linear combination. Environ. Earth Sci. 2015, 74, 4119-4131. [CrossRef]

29. Malinowska, A.; Matonóg, A. Sinkhole hazard mapping with the use of spatial analysis and analytical hierarchy process in the light of mining-Geological factors. Acta Geodyn. Geomater. 2017, 14, 2159-2172. [CrossRef]

30. Goepel, K.D. Implementing the analytic hierarchy process as a standard method for multi-criteria decision making in corporate enterprises-A new AHP excel template with multiple inputs. In Proceedings of the International Symposium on the Analytic Hierarchy Process, Kuala Lumpur, Malaysia, 23-26 June 2013.

31. Saaty, T.L. Relative Measurement and its Generalization in Decision Making Why Pairwise Comparisons are Central in Mathematics for the Measurement of Intangible Factors the Analytic Hierarchy/Network Process. Rev. Real Acad. Cienc. Exactas Fis. 2008, 102, 251-318. [CrossRef]

32. Heflik, W. On the possibilities of using serpentinites. Polish Stone Mag. 2015, 4, 66-67. (In Polish)

33. Bolewski, A.; Michałek, Z.; Skawina, T.; Kamieniecki, F.; Tymiński, S.; Polak, T.; Greszta, J. The Method of Reclamation of Post-industrial Wastelands and Sand Dunes and Improvement of the Properties of Light and Peat Soils. Patent PRL 53762, 1964. (In Polish)

34. Bolewski, A.; Michałek, Z.; Skawina, T.; Kamieniecki, F.; Tymiński, S. The Method of Obtaining Fertilizer with Mineral Sorbent. Patent PRL 53142, 1965. (In Polish)

35. Tronina, S.; Augustyn, D.; Dobrzański, Z.; Jamroz, D.; Kukla, S.; Mazurkiewicz, M. Feed Additive for Poultry, Especially for Broiler Chickens and Forest Hens. Patent PL 122908, 1994. (In Polish)

36. Tryburski, J. Fertilization and Fertility of Soil in an Organic Farm-Materials for Farmers; National Center for Organic Agriculture-Regional Center for Advisory Services for Agriculture and Rural Development in Radom: Radom, Poland, 2004; pp. 4-5. (In Polish)

37. Derkowska-Sitarz, M.; Zagożdżon, K. Granules Supporting the Cultivation of Plants and the Method of its Production. Patent PL 210673, 2009. (In Polish) 